\title{
First record of Miniopterus schreibersii (Chiroptera: Miniopteridae) in Poland-a possible range expansion?
}

\author{
Krzysztof Piksa ${ }^{1}$ (1) - Wojciech J. Gubała ${ }^{2}$ \\ Received: 19 February 2020 / Accepted: 30 August 2020 / Published online: 11 September 2020 \\ (C) The Author(s) 2020
}

\begin{abstract}
Schreiber's bent-winged bat Miniopterus schreibersii is a typical Mediterranean species. To date, the northern limit of its distribution range ran along the northern ends of Slovakia. This paper describes the first record of this species in Poland, at a more northerly site for this part of Europe. On October 7, 2015, an adult female of $M$. schreibersii was caught in the underground part of the New Castle in Rożnów, southern Poland (49 46' 23.8' N, 20 41' 43.1" E; 339 m a.s.1.). Subsequent observations were made at the same site during the autumn of 2018 and 2019. The likely migration route and the causes for a widening of the species distribution range are discussed in this paper. Observations suggest that, like other Mediterranean species, it has expanded its range in northerly direction.
\end{abstract}

Keywords Distribution $\cdot$ Carpathians $\cdot$ Southern Poland $\cdot$ Northern range $\cdot$ First record

\section{Introduction}

Miniopterus schreibersii is a species widely spread in the south-western Palaearctic biogeographic realm. It is patchily distributed over its range. It is a typical Mediterranean faunal element occurring in coastal North Africa (Morocco, Algeria, Tunisia and Libya), southern Europe (Iberian, Italian and Balkan peninsula) and in warm regions of west and central Europe. It is also present in coastal Anatolia, Cyprus, the Levant and western Transcaucasia (Bilgin et al. 2012, 2016; Šrámek et al. 2013; Puechmaille et al. 2014; Benda and Paunović 2019). The territory of Slovakia represents the northern edge of its natural distribution (Uhrin et al. 1997; Matis et al. 2012; Cel'uch 2014). In southern Europe and Anatolia, it is a widely distributed and is a common bat species.

Communicated by: Zuzanna Hałat

Krzysztof Piksa

krzysztof.piksa@up.krakow.pl

1 Department of Zoology, Institute of Biology, Pedagogical University of Krakow, Podchorążych 2, 30-084 Kraków, Poland

2 Chiropterological Information Center, Institute of Systematics and Evolution of Animals, Polish Academy of Sciences, Sławkowska 17, 31-016 Kraków, Poland
Population trends vary in different parts of the species distribution range: In most of south-eastern Europe, it appears to be stable (Turkey, Bulgaria, Croatia), whereas at the end of the twentieth century, the populations of $M$. schreibersii declined dramatically in northern and western parts of the European range. Extinction has occurred in Germany and Ukraine (Benda and Paunović 2019), and strong decline of populations was observed in Slovakia, Austria, Switzerland, Hungary and Romania (Lehotská and Lehotský 1995; Matis et al. 2012; Bohnenstengel et al. 2014; Benda and Paunović 2019).

In Europe, the species is listed as "Near Threatened" with a decreasing population trend (Benda and Paunović 2019). As a migratory species, it is included in the Bonn Convention (EUROBATS) and the Bern Convention, in the parts of the distribution range where these apply. It is also included in Annex II (and IV) of the EU Habitats and Species Directive, and hence requires special measures of conservation, including the designation of Special Areas for Conservation.

To date, there were no record of this species in Poland, with the closest observations from the neighbouring country Slovakia, $0.5 \mathrm{~km}$ away at Malé Osturnianske Jazero Lake and $2 \mathrm{~km}$ away at Aksamitka Cave (Cel'uch 2014). Thus, Cel'uch (2014) predicted that it is highly probable that because of its large home range, this species may also appear in Poland.

The aim of this paper is to present the details relating to the first finding of M. schreibersii in Poland, recorded during broad scale bat survey in the area of Rożnowskie Foothills. 


\section{Results and discussion}

The research was carried out in the Rożnowskie Foothills (Western Carpathians) in the years 2015-2020.

This region has a diverse relief, with high hills, and deeply cut valleys from the Dunajec and Biała Rivers and their tributaries. Within the region, there are two reservoirs created by damming waters of the Dunajec River: the Rożnów Lake $\left(16.9 \mathrm{~km}^{2}\right)$, and the Czchów Lake $\left(3.5 \mathrm{~km}^{2}\right)$. The ecosystem is moderately transformed by human activities. Cultivated fields and meadows prevail in the river valleys, while forests are preserved on the steep slopes and near rivers and water reservoirs. There are several non-karst caves, artificial underground spaces (e.g. cellars and military defence structures) castles and sacred buildings, which are important bat shelters in this region.

Surveys were conducted by a combination of different methods: passive and active acoustic sampling to detect bat calls over watercourses, mist netting of bats in front of the cave's openings during swarming, winter monitoring of bats in caves and cellars and searching of nursery colonies of bats in castles, churches, bridges, etc. In total, 27 sites were inspected in the spring, summer and autumn, two caves and nine cellars were controlled in the winter, mist netting was carried out at the openings of two caves and in defence bastion called "belluard" and acoustic sampling was carried out during several nights along the Dunajec River.

During the field studies on October 7, 2015, a parous female of $M$. schreibersii was caught by hand in the underground of the New Castle in Rożnów (49 $46^{\prime} 23.8^{\prime \prime} \mathrm{N} 20^{\circ}$ 41' 43.1" E; $339 \mathrm{~m}$ a.s.1.). This female was found in day lethargy, in a small chamber in the ceiling of a stone cellar ( $3.5 \mathrm{~m}$ wide $\times 4.5 \mathrm{~m}$ long $\times 2.4 \mathrm{~m}$ high), within the lowest level of the castle. After measurement taken, bat was released on the spot. Colouration, appearance and dimensions (measurements) of the captured bat were in accordance with descriptions of the species and characteristics given in the identification guide (Dietz et al. 2009). The fur colouration of the captured female was greyish-brown on the dorsal side, and slightly lighter and more grey on the ventral side. The bat had a very short muzzle and a humped forehead. The ears were very short and triangular, not projecting beyond the top of the head. The wings were very long and narrow and at rest, the third and fourth fingers were bent to the inside in the joint between the 1st and 2 nd phalanges. The second phalanx of the third finger was about three times as long as the first phalanx (Fig. 1). External measurements of the specimen were as follows: weight $13.7 \mathrm{~g}$, head and body length $51.1 \mathrm{~mm}$, forearm length $45.1 \mathrm{~mm}$ and foot length $10.3 \mathrm{~mm}$.

In order to check whether the site is regularly used by the species, and when and if it appears in subsequent years, the following checks were performed in next years: at least three times during the period of spring migration, twice during the

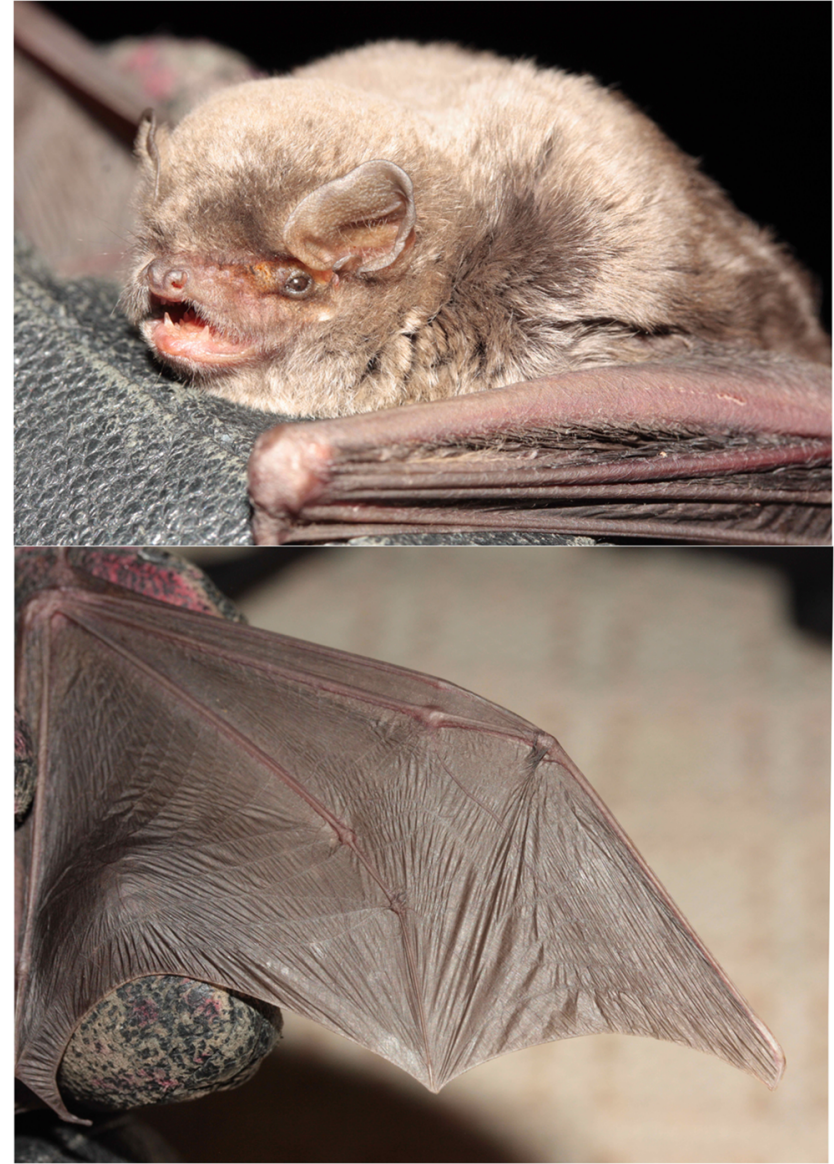

Fig. 1 Schreiber's bent-winged bat Miniopterus schreibersii caught in the New Rożnów Castle

summer activity period, at least four times during autumn migration period and once or twice during hibernation period. In 2016-2017 and in 2020, there was no presence of M. schreibersii. In 2018 (on October 2nd) and in 2019 (on September 12th), a single individual was observed. They roosted respectively in the previously described cellar and on the ceiling in one of the corridors at the lowest level of the castle. In 2018, the bat was left undisturbed in order to check how long it would stay in the roost, and in the subsequent year, the bat hung too high to be taken down. In both cases, after several days (four and six, respectively), the bats were not present during the next survey. In the castle, reproducing colonies of the greater mouse-eared bat Myotis myotis (numbering up to 119 individuals), Daubenton's bat Myotis daubentonii (up to 45 individuals) and the lesser horseshoe bat Rhinolophus hipposideros (up to 11 individuals) were also observed. We did not detect M. schreibersii with hand held detectors or mistnetings.

The finding of $M$. schreibersii in Rożnów during the autumn migration, the short time of the presence of bats and its absence in summer and winter periods indicates that the site is used by bats as a stop-off site (transient quarters) during 
migration. Presence of this species in the castle in Rożnów, as well as species with similar requirements such as M. myotis, with which it often forms mixed colonies (Dietz et al. 2009), indicates that it finds favourable conditions here.

Due to the presence of this bat species and others from Annex II of the Habitats Directive, it would be appropriate to protect the site, limit access to places where bats are roosting and include the castle and its surroundings to the nearest Nature 2000 area - Ostoje Nietoperzy Okolic Bukowca PLH120020 (bat sites near Bukowiec).

This record represents the first evidence of this bat species, as well as a new family (Miniopteridae) in Poland. This is also the northernmost site in Europe. The New Castle in Rożnów lies nearly $45 \mathrm{~km}$ further north than the previous most northerly site of this species (Aksamitka Cave, Pieniny Mts, Slovakia; Cel'uch 2014).

Miniopterus schreibersii is a regional migrant species with a relatively fast flight, whose seasonal displacement distances vary widely (Hutterer et al. 2005). Rivers can provide convenient migration routes and act as potential landmarks in the orientation flight of this bat (Serra-Cobo et al. 1998, 2000). The River Dunajec flows directly in the vicinity $(3 \mathrm{~km}$ in a straight line for some reaches) of the northernmost site of the species to date, i.e. the Aksamitka Cave, on the southern slopes of the Pieniny Mountains. It also flows in the direct vicinity of the ruins of the Rożnów Castle, at only $450 \mathrm{~m}$ distance between the river and the ruins (Fig. 2). The distance between these two sites amounts to approximately $48 \mathrm{~km}$ in the straight line, and approximately $85-88 \mathrm{~km}$ along the water course. Because of its location, the Dunajec River seems to be a perfect migration route that allows bats to fly from the previously northernmost site of this species towards Rożnów (facilitating its expansion towards the north). Importantly, the river flows through the massif of Pieniny and allows bats to cross the greatest geographical barrier in this region of Europe, which usually limits the spatial distribution and migrations of other animals to the north, i.e. the arc of the Carpathians.

The three sightings of $M$. schreibersii in the Castle of Rożnów during the autumn migration period are also indicative of its fairly regular attempts to migrate northward, using this location as a stop-off site. It is difficult to determine how far north it could reach. The Dunajec River is a right-bank tributary of the longest Polish river, the River Vistula, which flows to the north and discharges into the Baltic Sea. In the areas adjacent to these rivers, there are many features, including castles, sacred buildings with spacious attics, caves and mines that can be used by this species as summer, transition or winter quarters. Therefore, the rivers and their surroundings allow further unimpeded expansion of the species in this direction, although this will require further studies.

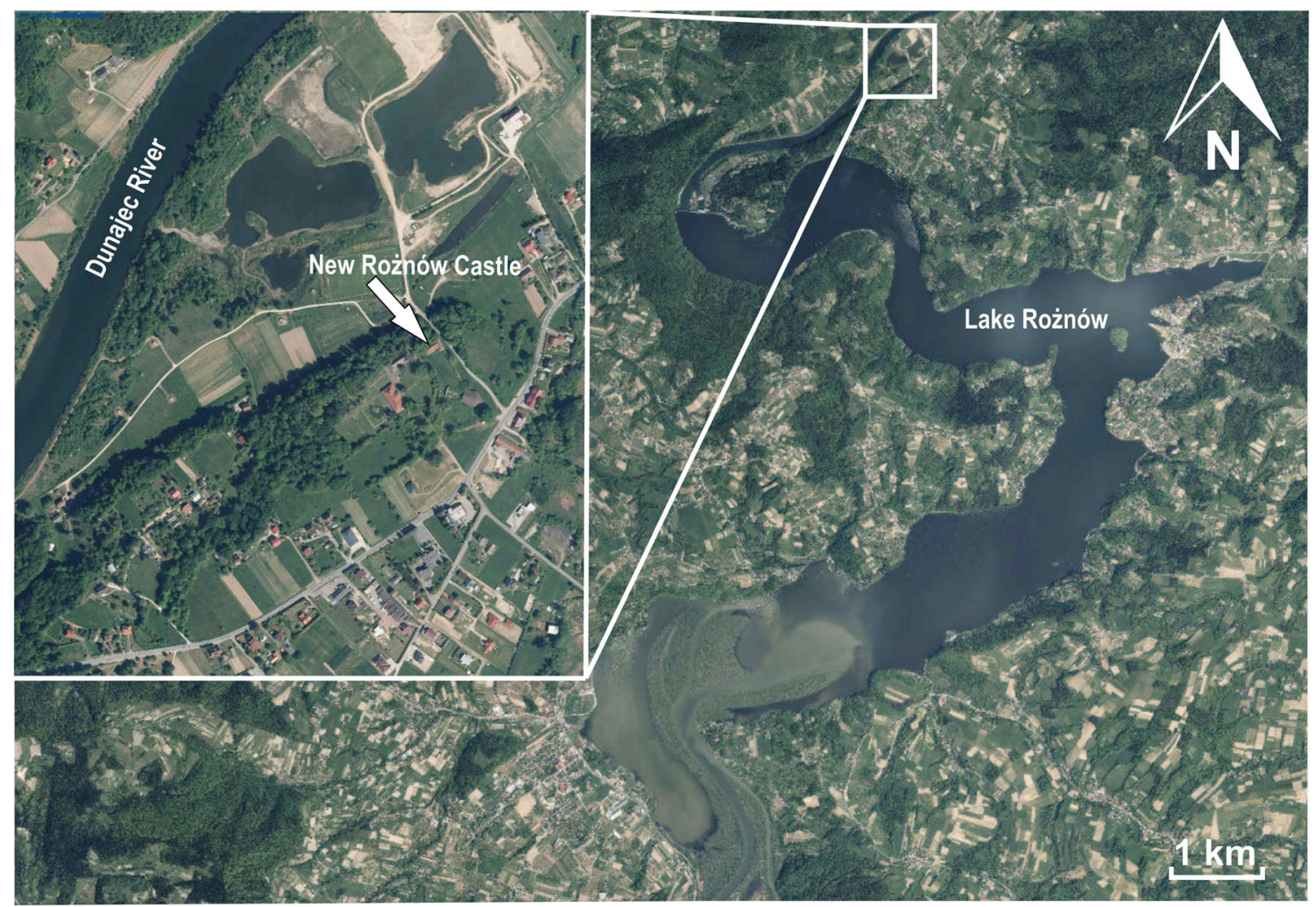

Fig. 2 Location of the New Rożnów Castle (source map: geportal.gov.pl) 
Fig. 3 Dense range (the area marked in grey) and the northernmost sites of Miniopterus schreibersii in Central Europe. (1) New Castle in Rożnów, (2) Aksamitka Cave (re-colonized site), (3) Malé Osturnianske Jazero Lake, (4) Hranická propast (Hranická Chasm)

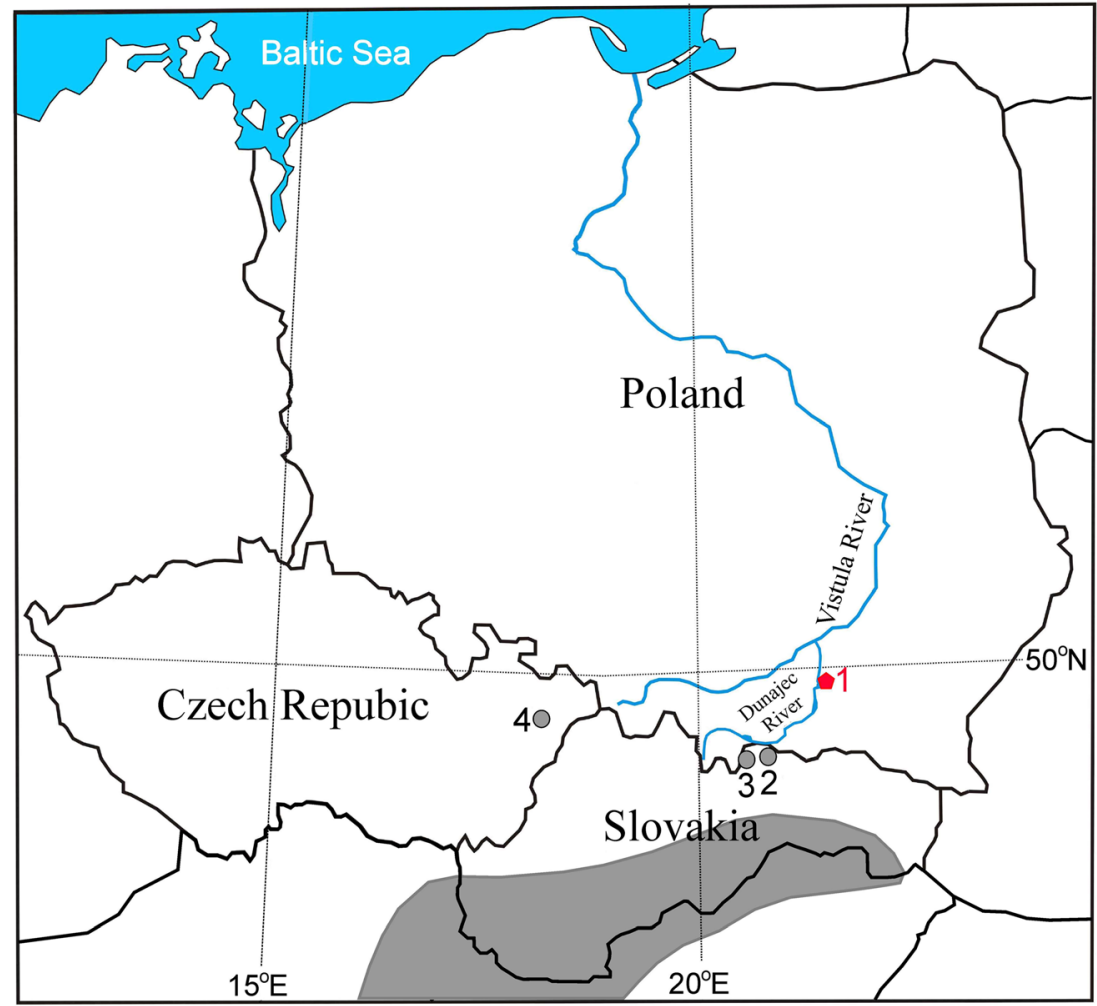

The finding of M. schreibersii in Poland, as well as appearance of the species in the Czech Republic (Bartonička and Jedlička 2011), and re-colonization of sites and appearance in new regions in north Slovakia (Cel'uch 2014) (Fig. 3), indicate that, like other Mediterranean species such as Myotis blythii (Piksa 2006), Hypsugo savii (Uhrin et al. 2016) and Pipistrellus kuhlii (Sachanowicz et al. 2006), M. schreibersii has expanded its range in northerly direction. It seems that the enlargement of the range to the north is a real process and not only the effect of an increase in field survey effort (although this cannot be excluded). Presumably the underlying reason for this expansion to the north is linked with climate changes, but it also cannot be excluded that the range expansion has been caused by anthropogenic factors (Cel'uch 2014).

\section{Compliance with ethical standards}

All procedures were carried out under licences from General Directorate for Environmental Protection (Decisions DZP-WG.6401.09.1.2014.km.2 and DZP-WG.6401.09.1.2017.dł).

Open Access This article is licensed under a Creative Commons Attribution 4.0 International License, which permits use, sharing, adaptation, distribution and reproduction in any medium or format, as long as you give appropriate credit to the original author(s) and the source, provide a link to the Creative Commons licence, and indicate if changes were made. The images or other third party material in this article are included in the article's Creative Commons licence, unless indicated otherwise in a credit line to the material. If material is not included in the article's Creative Commons licence and your intended use is not permitted by statutory regulation or exceeds the permitted use, you will need to obtain permission directly from the copyright holder. To view a copy of this licence, visit http://creativecommons.org/licenses/by/4.0/.

\section{References}

Bartonička T, Jedlička P (2011) First record of Miniopterus schreibersii in the Czech Republic (Chiroptera: Miniopteridae). Lynx ns 42:8389

Benda P, Paunović M (2019) Miniopterus schreibersii. The IUCN Red List of Threatened Species 2019: e.T81633057A22103918. https:// doi.org/10.2305/IUCN.UK.2019-1.RLTS.T81633057A22103918. en. Accessed 19 January 2020

Bilgin R, Gürün K, Maraci Ö, Furman A, Hulva P, Çoraman E, Lučan RK, Bartonička T, Horáček I (2012) Syntopic occurrence in Turkey supports separate species status for Miniopterus schreibersii schreibersii and M. schreibersii pallidus (Mammalia: Chiroptera). Acta Chiropterol 14:279-289. https://doi.org/10.3161/ 150811012 X661611

Bilgin R, Gürün K, Rebelo H, Puechmaille SJ, Maraci Ö, Presetnik P, Benda P, Hulva P, Ibáñez C, Hamidovic D, Fressel N, Horáček I, Karataş A, Karataş A, Allegrini B, Georgiakakis P, Gazaryan S, Nagy ZI, Abi-Said M, Lučan RK, Bartonička T, Nicolaou H, Scaravelli D, Karapandža B, Uhrin M, Paunović M, Juste J (2016) Circum-Mediterranean phylogeography of a bat coupled with past environmental niche modeling: a new paradigm for the recolonization of Europe? Mol Phylogenet Evol 99:323-336. https://doi.org/ 10.1016/j.ympev.2016.03.024 
Bohnenstengel T, Krättli H, Obrist M. K, Bontadina F, Jaberg C, Ruedi M, Moeschler P (2014) Liste rouge Chauves-souris. Espèces menacé esen Suisse, état 2011. Office fédéral de l'environnement, Berne, Centre Suisse de Cartographie de la Faune, Neuchâtel; Centre ssuisses de coordination pour l'étude et la protection des chauve ssouris, Genève et Zurich, Institut fédéral de recherches sur la forêt, la neige et le paysage, Birmensdorf L'environnement pratique 1412

Cel'uch M (2014) Return of Miniopterus schreibersii to the northern edge of its historical distribution in Slovakia. Vespertilio 17:59-63

Dietz C, Nill D, Helversen OV (2009) Bats of Europe and Northwest Africa. A \& C Black Publishers Ltd, London

Hutterer R, Ivanova T, Meyer-Cords Ch, Rodrigues L (2005) Bat migrations in Europe. A Review of Banding Data and Literature Naturschutz und BiologischeVielfalt 28

Lehotská B, Lehotský R (1995) Lietavec stahovavý (Miniopterus schreibersii) opät v malý karpatoch. In: Urban P (ed.)Výskum a ochrana cicavcov na Slovensku II. Zborník referátov z konferencie (Zvolen, 13.-14.10. 1995). Slovenská agentúra životného prostredia, Banská Bystrica, pp 87-92

Matis Š, Uhrin M, Danko Š, Krištofík J (2012) Lietavec st'ahovavý (Miniopterus schreibersii) [Schreibers' bat - Miniopterus schreibersii]. In: Krištofík J, Danko Š (eds) Cicavce Slovenska rozšírenie, bionómia a ochrana [Mammals of Slovakia Distribution, Life History and Protection]. Veda, Bratislava, pp 294-298

Piksa K (2006) First record of Myotis blythii in Poland. Lynx n s 37:197200

Puechmaille SJ, Allegrini B, Benda P, Gürün K, Šrámek J, Ibáñez C, Juste J, Bilgin R (2014) A new species of the Miniopterus schreibersii species complex (Chiroptera: Miniopteridae) from the
Maghreb Region, North Africa. Zootaxa. 3794(1):108-124. https:// doi.org/10.11646/zootaxa.3794.1.4

Sachanowicz K, Wower A, Bashta AT (2006) Further range extension of Pipistrellus kuhlii (Kuhl, 1817) in central and eastern Europe. Acta Chiropterol 8:543-548. https://doi.org/10.3161/1733-5329(2006) 8[543:FREOPK]2.0.CO;2

Serra-Cobo J, Sanz-Trullén V, Martínez-Rica JP (1998) Migratory movements of Miniopterus schreibersii in the north-east of Spain. Acta Theriol 43(3):271-283

Serra-Cobo J, Lopez-Roig M, Marques-Bonet T, Lahuerta E (2000) Rivers as possible landmarks in the orientation flight of Miniopterus schreibersii. Acta Theriol 45(3):347-352

Šrámek J, Gvoždík V, Benda P (2013) Hidden diversity in bent-winged bats (Chiroptera: Miniopteridae) of the Western Palaearctic and adjacent regions: implications for taxonomy. Zool J Linnean Soc 167: 165-190. https://doi.org/10.1111/j.1096-3642.2012.00870.x

Uhrin M, Lehotská B, Benda P, Lehotský R, Matis Š (1997) Rozšírenie netopierov na Slovensku. Čast' 3, Miniopterus schreibersi [Distributional patterns of bats in Slovakia. Part 3, Miniopterus schreibersi]. Vespertilio 2:113-130

Uhrin M, Hüttmeir U, Kipson M, Estók P, Sachanowicz K, Bücs S, Karapandža B, Paunović M, Presetnik P, Bashta AT, Maxinová E, Lehotská B, Lehotský R, Barti L, Csösz I, Szodoray-Paradi F, Dombi I, Jére C, Pocora I, Benda P (2016) Status of Savi's pipistrelle Hypsugo savii (Chiroptera) and range expansion in Central and south-eastern Europe: a review. Mammal Rev 46:1-16. https://doi. org $/ 10.1111 /$ mam. 12050

Publisher's note Springer Nature remains neutral with regard to jurisdictional claims in published maps and institutional affiliations. 